\title{
Analisis Tingkat Ketangguhan Bencana Kelurahan Di Kota Ternate (Studi Kasus Pandemi Covid 19)
}

\author{
${ }^{1}$ Marwan ${ }^{2}$ Abdurrachman Baksir ${ }^{3}$ Jannati \\ ${ }^{1}$ Fakultas Ekonomi dan Bisnis, Universitas Khairun \\ ${ }^{2}$ Fakultas Ilmu Kelautan dan Perikan, Universitas Khairun \\ ${ }^{3}$ Program Studi Manajemen, STIEM Bongaya \\ Email: marwan.jamaluddin@yahoo.co.id
}

\begin{tabular}{l}
\hline Article Info \\
\hline Article history: \\
Article Accepted: June 032021 \\
Publication : July 072021 \\
\end{tabular}

Keywords:

Disaster Resistant, Pandemic, Covid 19

\begin{tabular}{l}
\hline Article Info \\
Article history: \\
Article Accepted: June 032021 \\
Publication: July 072021 \\
\hline
\end{tabular}

Keywords:

Tangguh Bencana, Pandemi, Covid 19

\begin{abstract}
The purpose of this study was to determine the level of government readiness at the kelurahan level in Ternate City in dealing with disasters by taking samples from 10 kelurahan as representatives of 77 kelurahan. This research was conducted with a qualitative approach, the interactive model. The results of the study revealed that the resilience level of the 10 urban villages was still in the low category. This is because there are only 3 sub-districts that are in the medium category, 5 sub-districts, and even 2 have not been categorized. This finding reveals that the level of village resilience to disasters is in the low category contributing to the weak handling of the COVID-19 pandemic in the City of Ternate in their respective environments. As a result of the government's lack of planning and preparation in dealing with the fast-spreading epidemic, the handling is very slow. Even impressed. The lack of strong disaster management institutionalization for the wider community causes the level of public understanding of disaster management to be low so that the level of awareness and sympathy of the community towards other communities is also low. This condition encourages the emergence of public attitudes that are contrary to the protocol for handling the covid pandemic. Not having made disaster management one of the government's priorities, disaster management, including COVID-19, always seems slow
\end{abstract}

\begin{abstract}
Abstrak
Tujuan penelitian ini untuk mengetahui tingkat kesiapan pemerintah pada tingkat kelurahan di Kota Ternate dalam menghadapi bencana dengan mengambil sampel pada 10 kelurahan sebagai representasi dari 77 kelurahan. Penelitian ini dilakukan dengan pendekatan kualitatif, Model Interaktif. Hasil penelitian mengungkapkan bahwa tingkat ketahanan 10 kelurahan tersebut masih berada dalam kategori rendah. Hal ini dikarenakan hanya ada 3 kecamatan yang masuk kategori sedang, 5 kecamatan, bahkan 2 belum masuk kategori. Temuan ini mengungkapkan bahwa tingkat ketahanan kelurahan terhadap bencana berada pada kategori rendah berkontribusi terhadap lemahnya penanganan pandemi COVID-19 di Kota Ternate di lingkungannya masing-masing. Akibat minimnya perencanaan dan persiapan pemerintah dalam menghadapi wabah yang sangat cepat menyebar menyebabkan penanganan berjalan sangat lamban. Bahkan terkesan grogi. Kurangnya pelembagaan penanggulangan bencana yang kuat bagi masyarakat luas menyebabkan tingkat pemahaman masyarakat terhadap penanggulangan bencana menjadi rendah sehingga tingkat kesadaran dan simpati masyarakat terhadap masyarakat lain juga rendah. Kondisi ini mendorong munculnya sikap masyarakat yang bertentangan dengan protokol penanganan pandemi covid. Belum menjadikan penanggulangan bencana sebagai salah satu prioritas pemerintah, penanggulangan bencana, termasuk COVID-19, selalu terkesan lamban.
\end{abstract}

This is an open access article under the Lisensi Creative Commons Atribusi-BerbagiSerupa 4.0 Internasional

Corresponding Author:

Mawan

${ }^{1}$ Fakultas Ekonomi dan Bisnis, Universitas

Khairun

Email: marwan.jamaluddin@yahoo.co.id

\section{PENDAHULUAN}

Berdasarkan pada letak geografisnya Indonesia menjadi dalah satu negara yang berada pada jalur ring of fire atau biasa disebut juga dengan cincin api. Hal ini menandakan bahwa 
untuk wilayah Indonesia menjadi salah satu negara yang memiliki potensi yang sangat tinggi terhadap terjadinya gempa bumi dan bencana bencana alam lainnya. Bahkan cincin api pasifik adalah merupakan sebuah jalur pegunungan aktif yang mempertemukan 3 lempengan, yaitu lempeng Pasifk, Eurasia dan juga lempeng Indo - Asia.

Dengan keadaan yang seperti itu, maka dapat disimpulkan bahwa masyarakat Indonesia sangat rawan bagi terjadinya bencana alam yang sewaktu-waktu dapat mengancam keselamatan mereka. Tercatat dalam beberapa tahun belakang ini berbagai jenis bencana telah menimpa masyarakat Indonesia di berbagai daerah. Diantaranya adalah bencana banjir, tsunami, tanah longsor, gempa, dan lain-lain. menurut data dari BNPBP pada tahun 2018 tercatat sebanyak 3.397 kali , pada tahun 2019 yang lalu tercatat jumlah bencana yang terjadi di seluruh Indonesia dengan segala klasifikasi dari yang kecil, sedang, hingga besar terdapat sebanyak sampai dengan bulan desember tercatat sebanyak 3.768 kali dan sejak tahun 2020 ini telah tercatat jumlah bencana yang terjadi sebanyak 1.927 kali pada periode januari sampai dengan agustus.

Salah satu bencana yang terbaru dan terbilang fenomenal sebab menyebabkan lumpuhnya berbagai aktifitas manusia di seluruh dunia, yaitu berupa wabah penyekit menular Covid 19 yang oleh Badan Kesehatan Dunia (WHO) diktegorikan merupakan pandemi global karena melanda hampir di seluruh dunia. Seperti yang dilakukan oleh sebagian negara dengan melakukan Lock down total, yakni dengan mengisolasi wilayahnya dari orang yang akan masuk maupun orang yang akan keluar. Artinya dalam jangka waktu tertentu wilayah itu melarang orang untuk keluar maupun masuk.

Provinsi Maluku sendiri sebagai salah satu daerah transit yang memiliki tingkat perputaran masyarakatnya cukup tinggi melalui masuknya orang dari luar negeri dan dari luar daerah telah ikut dihebohkan dengan kasus tersebut. Berbagai langkah-langkah awal telah dilakukan oleh pemerintah daerah berdasarkan pada rekomendasi dari pemerintah pusat melalui instansi terkait. Berbagai upaya tersebut dilakukan di dalam rangkah melakukan pencegahan bagi terjadinya penyebaran yang lebih luas lagi. Berbagai aktifitas yang dianggap memiliki potensi tinggi bagi terjadinya penularan segera ditiadakan. terutama bagi kegiatan yang merupakan yang menjadi pusaran untuk berkumpulnya orang banyak. Diantaranya diliburkannya semua aktifitas perkantoran pemerintah dan digesernya kegiatan yang dapat dilaksanakan dari rumah yang kemudian dikenal dengan sebut Work From Home (WFH) kecuali pada bebrapa instansi yang tidak dapat diliburkan seperti rumah sakit, kepolisian, dan beberapa unit yang sifatnya kedaruratan, sekolah-sekolah dan kampus pun ikut dilburkan. Bahkan terdapat yang lebih ekstri yakni dilakukannya pembebasan sebagaian tahanan dalam rangka mengurangi para napi. Selain itu, protokol kesehatan diterapkan secara ketat pada instansi yang tetap menjalankan layanan publik. seperti diwajibkannya bagi setiap instansi untuk menyediakan tempat cuci tangan, diwajibkannya pengenaan masker, dan dilkukannya pemeriksaan suhu tubuh.

Tinginya korban yang terjadi di berbagai negara dan daerah di Indonesia yang selalu secara rutin diinformasikan pada berbagai media setiap hari pada tahap awal membuat masyarakat secara suka rela mengikuti berbagai kebijakan yang ditetapkan oleh pemerintah. Namun seiring dengan berjalannya waktu yang terus berjalan sementara hasil dari kebijakan tersebut untuk memutuskan mata rantai penyebaran tidak kunjung terlihat lambat laun menyebabkan munculnya perilaku perlawanan dari sebagian masyarakat.

Namun demikian, berbagai kebijakan yang dilakukan pemerintah tersebut belum menunjukkan hasil yang efektif. Bahkan saat ini malah terjadi saling tuding diantara pihak, baik antara masyarakat, masyarakat dengan pemerintah, maupun antara pemerintah dengan pemerintah sendiri. Kondisi ini tidak ubahnya seperti benang kusut yang tidak menampakkan ujung pangkalnya sehingga sangat sulit untuk dapat diurai.

Selanjutnya, semangat Undang-undang nomor 24 tahun 2007 tentang penanggulangan bencana serta Peraturan Pemerintah nomor 21 tahun 2008 tentang penyelenggaran penanggulangan bencana telah merubah paradigma penanggulangan bencana di Indonesia dari 
konsep tanggap darurat yang bersifat responsif menjadi konsep pengurangan risiko bencana yang bersifat preventif. Penanggulangan bencana tidak hanya terpusat pada upaya tanggap darurat dan rehabilitasi serta rekonstruksi pasca bencana tetapi lebih diarahkan pada tahapan sebelum terjadinya (pra bencana) melalui upaya peningkatan kapasitas masyarakat terhadap bencana. Oleha karena itu, penanggulangan bencana bukan semata menjadi tanggung jawab pemerintah semata tetapi harus melibatkan masyarakat secara luas dalam setiap pase bencana tersebut.

Manajemen Risiko Bencana Berbasis Masyarakat (CBDRM) merupakan proses di mana komunitas (masyarakat) secara aktif terlibat didalam identifikasi, analisis, penanganan, pemantauan dan evaluasi dari risiko bencana dalam upaya mengurangi kerentanan dan meningkatkan kemampuan mereka (Mc Laughlin, 2007). Hasil dari penelitian sebelumnya tentang Studi Ketahanan Masyarakat Pesisir Pacitan terhadap Bencana Tsunami, masyarakat Pacitan masih memiliki indeks ketahanan yang rendah dalam pengetahuan tentang risiko, peringatan dan evakuasi serta respon terhadap keadaan darurat (Pradana, 2012).

Tujuan pengurangan risiko adalah untuk merancang dan membuat konteks untuk mengurangi kerugian manusia danmelindungi aset dari bahaya alam, Blaikie dkk. 2014; Dowrick 2009 dalam Valibeigi et all (2019:2). Selanjutnya, oleh karena itu Disaster Risk Management (DRM) terdiri dari berbagai kegiatan sebelum, selama dan setelah bencana, dilakukan untuk meminimalkan kerentanan dan risiko bencana di seluruh masyarakat, untuk menghindari atau membatasi dampak buruk dari bahaya, dalam konteks luas pembangunan berkelanjutan dan memperhatikan dimensi seperti partisipasi,penguatan sinergi dan pengetahuan, pemberdayaan dan meningkatkan kapasitas, memperbaiki lingkungan fisik dan kemampuannya (ISDR 2005; Kohler, Julich \& Bloemertz 2004; Thomalla et al. 2006), Valibeigi (2019:2).

\subsection{Rumusan Masalah}

"Bagaimana tingkat kesiapan pemerintah di tingkat kelurahan di Kota Ternate dalam menghadapi potensi bencana yang terjadi terkait penyebaran Covid 19?

\subsection{Tujuan}

Untuk mengetahui tingkat kesiapan pemerintah di tingkat kelurahan di Kota Ternate dalam menghadapi potensi bencana yang terjadi terkait penyebaran Covid 19.

\section{KAJIAN PUSTAKA}

\subsection{Bencana Alam}

Menurut United Nations Development Programme (dalam Febri:2017), bencana merupakan suatu gangguan yang cukup serius bagi masyarakat karena menimbulkan kerugian terhadap manusia, material serta lingkungan, yang akibatnya melebihi kemampuan masyarakat korban tertimpa bencana, dan dalam penanggulanggannya hanya berasal dari sumber daya masyarakat itu sendiri. Menurut Priambodo (2013), bencana merupakan sebuah kejadian alam yang disebabkan oleh perbuatan manusia ataupun gabungan dari keduanya yang terjadi secara mendadak sehingga berdampak negatif untuk kehidupan makhluk hidup. Bencana adalah suatu peristiwa, entah karena perbuatan manusia atau alam, mendadak atau berangsur yang menyebabkan kerugian yang meluas terhadap kehidupan, materi dan lingkungan sedemikian rupa melebihi kemampuan dari masyarakat korban untuk menanggulangi dengan menggunakan sumber dayanya sendiri (Nasution:2005). Senada dengan definisi tersebut dijelaskan oleh Surono (2003) bencana adalah peristiwa yang diakibatkan oleh alam dan atau manusia yang dapat mengakibatkan jatuhnya korban jiwa dan harta benda, kerusakan lingkungan hidup, sarana dan prasarana, fasilitas umum serta mengganggu tata kehidupan dan penghidupan masyarakat.

Menurut Kusumasari (2014) penanggulangan bencana meliputi 5 tahapan umum: Tahap pertama, Prediction (prediksi): dalam tahap ini kegiatan mitigasi dan kesiapsiagaan dilakukan. Tahap kedua, Warning (peringatan): tahap ini mengacu pada 
penyediaan informasi yang efektif dan tepat waktu melalui lembaga-lembaga yang teridentifikasi. Tahap ketiga, Emergency relief (bantuan darurat): tahap ini merujuk pada penyediaan bantuan atau intervensi selama atau setelah bencana terjadi. Tahap keempat, Rehabilitation (rehabilitasi): tahap ini meliputi keputusan dan tindakan yang diambil setelah bencana untuk memulihkan atau mengembalikan kondisi kehidupan masyarakat yang terkena bencana seperti kondisi sebelum bencana terjadi. Tahap kelima, Reconstruction (rekonstruksi): tahap ini merujuk pada pembangunan kembali kondisi kehidupan masyarakat yang telah rusak akibat bencana dengan tujuan pembangunan jangka panjang yang berkelanjutan. Penanggulangan bencana terdapat 4 aktifitas siklus yang sangat penting dilakukan yaitu mitigasi, kesiapsiagaan, respons, dan pemulihan (Alexander; Coppola; King; Moe \& Pathranarakul; Quarantelli dalam Kusumasari, 2014:21):

\subsection{Covid 19}

Menurut Montes (2020:2572) bahwa pandemic global penyakit virus korona 2019 (Covid - 19) merupakan sindrom pernapasan akut parah coronavirus 2 (SARS - CoV - 2 adalah peristiwa yang belum perna terjadi sebelumnya membebani layanan kesehatan di seluruh dunia.

Guan (2020:1709) menjelaskan bahwa dalam studi terbaru, tingkat keparahan beberapa kasus Covid - 19 meniSARSCoV1,12,13 mengingat penyebaran cepat Covid - 19, kami menentukan bahwa analisis kasus yang diperbaharui di seluruh daratan China mungkin membantu mengidentifikasi karakteristik klinis yang menentukan dan tingkat keparahan penyakit. Lebih lanjut Guan (2020: 1710) merinci tentang ciri spesifik dari Covid 19 ini adalah sebagai berikut, demam didefenisikan sebagai suhu ketiak $37,5^{\circ} \mathrm{C}$ atau lebih tinggi. Limfositopenia disefenisikan sebagai jumlah limfosit kurang dari 1500 sel per millimeter kubik. Trombositopenia itu didefenisikan sebagai jumlah trombosit kurang dari 150.000 permilimeter kubik. Defenisi tambahan termasuk paparan satwa liar, pernapasan akut distress Syndrome (ARDS), pneumonia, akut gagal ginjal, gagal jantung akut, dan rhabdomyolysis.

\subsection{Desa Tangguh Bencana}

Desa Tangguh Bencana merupakan salah satu program dari Badan Nasional Penanggulangan Bencana (BNPB). Adapun pengertian dari Desa Tangguh Bencana menurut Perka BNPB No 1 Tahun 2012 adalah sebuah desa ataupun kelurahan yang berkemampuan mengetahui ancaman yang akan terjadi di daerahnya serta mampu mengkoordinir sumber daya khususnya masyarakat guna meminimalisir kerentanan dan memaksimalkan kapasitas untuk pengurangan resiko bencana. Dapat disimpulkan bahwa Desa Tangguh Bencana adalah desa atau kelurahan yang berkemampuan mandiri dalam hal beradaptasi dan juga mampu menghadapi potensi adanya ancaman bencana, serta mampu untuk memulihkan diri dengan cepat atas dampak dari bencana yang merugikan.

Organisasi masyarakat, dan kelompok-kelompok lainnya yang peduli Komponenkomponen Desa Tangguh Bencana (Destana) berdasarkan Perka BNPB No.1 Tahun 2012 antara lain:

1. Legislasi

Merupakan kegiatan penyusunan peraturan desa yang mengatur pengurangan risiko dan penanggulangan bencana di tingkat Desa.

2. Perencanaan

Penyusunan rencana Penanggulangan Bencana Desa, yang meliputi: rencana kontijensi bila menghadapi ancaman tertentu, dan Rencana Aksi Pengurangan Risiko Bencana Komunitas.

3. Kelembagaan

Pembentukan forum Penanggulangan Bencana Desa yang berasal dari unsur pemerintah dan masyarakat, kelompok/tim relawan penanggulangan bencana di 
dusun, RW dan RT, serta pengembangan kerjasama antar sektor dan pemangku kepentingan dalam mendorong upaya pengurangan risiko bencana.

4. Pendanaan

Rencana mobilisasi dana dan sumber daya (dari APBD kabupaten/kota,APBDes/ADD, dana mandiri masyarakat dan sektor swasta atau pihak-pihak lain bila dibutuhkan).

5. Pengembangan kapasitas

Pelatihan, pendidikan dan penyebaran informasi kepada masyarakat, khususnya kelompok relawan dan para pelaku penanggulangan bencana

6. Penyelenggaraan Penanggulangan Bencana

Kegiatan-kegiatan mitigasi fisik struktural dan non-fisik, sistem peringatan dini, kesiapsiagaan untuk tanggap darurat, dan segala upaya pengurangan resiko melalui intervensi pembangunan dan program pemulihan baik yang bersifat struktural -fisik maupun non-struktural.

\section{METODE PENELITIAN}

\subsection{Metode dan Tahapan analisis Kualitatif}

Penelitian ini dilakukan dengan pendekatan kualitatif, yakni Model Interaktif. Menurut Huberman dan Miles (Idrus, 2007:180-184), model interaktif terdiri atas tiga hal utama yaitu reduksi data, penyajian data, dan penarikan kesimpulan.

\subsection{Teknik pengumpulan data}

Teknik pengumpulan data dalam penelitian yaitu wawancara, kuisioner dan dokumentasi. Teknik pengumpulan data ini dipilih karena yaitu kuisioner, dokumentasi, dan wawancara.

\subsection{Analisis Data}

Untuk menganalisa data yang telah terkumpul dari hasil penelitian yang bersifat kuantitatif dengan menggunakan acuan pada Peraturan Kepala (Perka) Badan Nasional Penanggulangan Bencana Nomor 1 Tahun 2012 Tentang Pedoman Umum Desa/Kelurahan Tangguh Bencana di dalamnya memuat tentang ketentuan dan klasifikasi desa/kelurahan tangguh bencana sebagai berikut:

a. Desa/Kelurahan Tangguh Bencana Utama (Skor 51 - 60)

b. Desa/Kelurahan Tangguh Bencana Madya ((Skor 36 - 50)

c. Desa/Keluarahan Tangguh Bencana Pratama (Skor 20 - 35)

\section{HASIL DAN PEMBAHASAN}

\subsection{Hasil Penelitian}

Berdasarkan pada survey yang telah dilakukan terhadap 11 kelurahan yang berada di Kota Ternate diperoleh hasil sebagai berikut:

Tabel 1. Hasil Pengukuran Tingkat Ketangguhan 11 Kelurahan di Kota Ternate Tahun 2020

\begin{tabular}{|c|c|c|c|}
\hline No. & Kelurahan & Total Nilai & Klasifikasi \\
\hline 1 & Tanah Tinggi & 6 & - \\
\hline 2 & Toboleu & 10 & - \\
\hline 3 & Duifa-Dufa & 21 & Pratama \\
\hline 4 & Tarau & 23 & Pratama \\
\hline 5 & Tanah Tinggi Barat & 25 & Pratama \\
\hline 6 & Sango & 30 & Pratama \\
\hline 7 & Sasa & 34 & Pratama \\
\hline 8 & Bastiong Talangame & 40 & Madya \\
\hline 9 & Kalumata & 44 & Madya \\
\hline 10 & Mangga Dua & 48 & Madya \\
\hline
\end{tabular}

Sumber: Data Primer Yang Diolah 
Berdasarkan pada table 1, tersebut di atas, Nampak bahwa dari 11 kelurahan yang telah dilakukan survey, Nampak dari hasil olahan data yang telah dilakukan diperoleh hasil seperti di atas. Yaitu bahwa secara keseluruhan 11 kelurahan tersebut dapat dikelompokkan dalam 3 klasifikasi yakni, yang pertama adalah kelompok yang belum dapat memenuhi salah satu kriteria yang telah ditetapkan. Pada kelompok ini terdapat dua kelurahan, yaitu kelurahan Tanah Tinggi dan kelurahan Toboleu. Kelompok kedua yaitu yang masuk pada klasifikasi pratama, yang terdiri atas 6 kelurahan. Yaitu kelurahan Dufa-Dufa, Tarau,Tanah Tinggi Barat, Sango, dan Sasa. Kelompok ketiga adalah kelompok madya, yang terdiri atas 3 kelurahan yaitu Kelurahan Bastiong Talangame, Kalumata, dan

Terdapat 2 kelurahan yang secara kumulatif nilainya tidak mencukupi untuk masuk di dalam klasifikasi pratama. Sebab seperti disyaratkan bahwa sebuah kelurahan akan masuk pada kategori pertama yaitu pratama jika minimal mampu memiliki nilai total 20 , sementara itu untuk kelurahan dan kelurahan Toboleau hanya meraih nilai masing-masing 6 dan 10 . Selanjutnya terdapat 5 kelurahan berada pada kelompok madya dengan kisaran nilai berada pada $20-35$. Sementara itu, 3 kelurahan lainnya berada kelompok yang lebih baik, yakni madya dengan kisaran nilai $52-60$.

Hasil ini menunjukkan bahwa, jika total angka yang dijadikan dasar maka beberapa kelurahan di kota Ternate telah menyadari tentang perlunya membangun tingkat kesiapan dalam menghadapi bencana. Gambaran ini akan dapat memberikan perasaan aman bagi masyarakat oleh sikap yang pemerinth pada tingkat kelurahan yang sduah lebih bersikaap proaktif. Kendati pun demikian sikap ini memang harus diambil bahkan pada masa-masa yang akan datang perlu terus ditingkatkan sebab bagaimana pun sebuah bencana itu tidak perna diinginkan oleh siapapun tetapi kita harus menyadari bahwa potensi terjadinya selalu saja ada dengan berbagai bentuknya. Sehingga semua jajaran pemerintah harus selalu siap "menyambutnya". Demikian juga dengan skala dan dampaknya.

\subsection{Pembahasan Hasil Penelitian}

Dengan temuan seperti di atas maka secara umum dapat dirangkumkan terhadap keenam aspek yang dijadikan indicator di dalam penetapan tingkat ketangguhan sebuah wilayah, desa maupun kelurahan terhadapbencana, maka dapat dirangkumkan di dalam table berikut.

Tabel 2. Ringkasan Hasil Survey 10 Kelurahan Tahun 2020

\begin{tabular}{|c|c|c|c|c|c|c|}
\hline \multirow{2}{*}{ Kel. } & \multicolumn{6}{|c|}{ Nilai } \\
\hline & I & II & III & IV & V & VI \\
\hline Tanah Tinggi & $1 / 3$ & $0 / 3$ & $1 / 9$ & $1 / 6$ & $0 / 15$ & $3 / 24$ \\
\hline Toboleu & $3 / 3$ & $3 / 3$ & $2 / 9$ & $0 / 6$ & $0 / 5$ & $2 / 24$ \\
\hline Duifa-Dufa & $0 / 3$ & $0 / 3$ & $2 / 9$ & $2 / 6$ & $6 / 15$ & $11 / 24$ \\
\hline Tarau & $1 / 3$ & $0 / 3$ & $3 / 9$ & $1 / 6$ & $4 / 15$ & $13 / 24$ \\
\hline Tanah Tinggi Barat & $2 / 3$ & $1 / 3$ & $6 / 9$ & $2 / 6$ & $8 / 15$ & $6 / 24$ \\
\hline Sango & $2 / 3$ & $3 / 3$ & $4 / 9$ & $1 / 6$ & $4 / 15$ & $15 / 24$ \\
\hline Sasa & $2 / 3$ & $3 / 3$ & $4 / 9$ & $1 / 6$ & $4 / 15$ & $15 / 24$ \\
\hline Bastiog Talangam & $3 / 3$ & $2 / 3$ & $5 / 9$ & $5 / 6$ & $6 / 15$ & $13 / 24$ \\
\hline Kalumata & $3 / 3$ & $3 / 3$ & $9 / 9$ & $6 / 6$ & $12 / 15$ & $8 / 24$ \\
\hline Mangga 2 & $3 / 3$ & $2 / 3$ & $7 / 9$ & $5 / 6$ & $9 / 15$ & $17 / 24$ \\
\hline
\end{tabular}

Sumber: Data Primer Yang diolah, 2020

Hasil ini mengungkapkan bahwa kesiapan keluarahan tersebut di dalam menghadapi kejadian atau peristiwa bencana masih sangat rendah. pada seluruh aspek, mulai dari pada aspek legislasi (I), perencanaan (II), Kelembagaan (III), Pendanaan (IV), Kapasitas (V), dan sampai kepada tahap penanganan bencananya (VI). 


\subsubsection{Aspek Legislasi}

Di Ternate sendiri pada tahap awal sangat dipenuhi dengan ketidakpastian. Ketidaksiapan pemerintah daerah dalam aspek regulasi menyebabkan terjadinya kekosongan komando di dalam menangani pandemic ini di tahap awal yang sesungguhnya menjadi fase yang sangat krusial. Sebab salah satu akibat dari ketiadaan regulasi tersebut adalah ketidakadaan pengelompokan bencana dan termasuk struktur penanganannya. Padahal seperti diketahui kecepatan penyebaran covid 19 ini memang sangat tinggi. Sehingga dapat dikatakan bahwa pada fase awal tersebut telah bekerja dua mekanisme yang sangat bertolak belakang. Pada satu sisi pandemic covid dengan sifatnya dan polanya terus bekerja dengan sangat keras bahkan ada bantuan dari perilaku masyarakat karena ketidaktahuannnya menjadi lebih cepat lagi . Tapi pada sisi yang lain, pemerintah daerah sangat lamban. Bahkan dapat dikatakan tidak berkeja. Hal ini karena ada kebingungan dalam birokrasi. Akhirnya terjadi saling tunggu dan saling tuding.

Kalau saja terdapat regulasi yang cukup pada tingkat desa atau kelurahan sebagai pemegang otoritas pemerintah terendah, maka akan terdapat beberapa tindakan yang dapat diambil untuk dapat menahan laju eskalasi wabah ini. Diantaranya adalah adanya kekuatan dan kepastian hokum bagi para kepala desa dan lurah untuk dapat menertibkan masyarakat untuk dapat mentataati protocol kesehatan yang telah ditetapkan oleh pemerintah. Seperti diketahui bahwa salah satu masalah terbesar di dalam penanganan persoalan wabah covid ini adalah terkait dengan bagaimana merubah perilaku masyarakat untuk menyesuiakan dengan tuntutan kebutuhan menghadapi wabah ini. Seperti yang telah diketahui bahwa pemerintah menerapkan slogan yang dikenal dengan singkatan $3 \mathrm{M}$, yakni menggunakan masker, mencuci tangan, dan menjaga jarak minimla 2 meter. Akan tetapi dalam penerapannya banyak mengalami resistensi dari masyarakat. Seperti masyarakat sangat enggan menggunakan masker dan masih suka melakukan kumpul bersama baik secara sembunyi-sembunyi maupun secara terang-terangan di tempat umum yang oleh pemerintah telah dihimbau untuk dilakukan penutupan. Bahkan tidak jarang masyarakat yang nekad melakukan berbagai hajatan yang melibatkan masyarakat banyak, yang di Ternate di kenal dengan sebutan pesta. Yang mana lazimnya pesta tersebut disertai dengan diadakannya perhelatan tarian masyarakat yang sangat rawan dengan terjadinya kontak fisik.

Hal lain yang dirasakan menjadi alasan yang lebih urgen bagi ketersediaannya regulasi pada tingkat desa dan kelurahan adalah dalam masa pandemic dan masa sulit lainnya adalah sering munculnya berbagai perilaku yang sifatnya opportunis. Yaitu perilaku sebagian masyarakat yang mencari untung tanpa memperhatikan pada kesulitan yang dihadapi oleh masyarakat lainnya. Seperti pada umumnya pada setiap terjadinya masalah social di masyarakat, termasuk juga pada peristiwa bencana alam akan menyebabkan terjadinya ketidaknormalan di dalam berbagai hal. Termasuk di dalam distribusi logistic. Hal ini pada gilirannya akan membawa pada ketidakseimbangan antara antara penawaran dan permintaan. Akibatnya adalah akan mendorong pada peningkatan harga jual di masyarakat. Kondisi ini diperparah dengan factor psikologis di masyarakat baik sebagai penjual maupun pada posisi pembeli. Yakni akan memunculkan perilaku penimbunan barang-barang oleh para penjual. Pada sisi yang lain, para pembeli akan melakukan aksi borong barang untuk dapat memastikan ketersediaan barang dan mengantisipasi pada terjadinya kelangkaan. Pengalaman yang berulang pada setiap terjadinya musibah menyebabkan kejadian yang sama terus berulang. Hal yang sama kembali terjadi dalam peristiwa covid 19 yang saat ini sedang berlangsung. Sehingga sangat dibutuhkan regulasi pada tingkat semua unit pemerintahan termasuk pada tingkat desa maupun lurah. Sehingga dapat membuat masyarakat memiliki keyakinan akan 
penanganan yang dilakukan oleh pemerintah. Minimal peran para kepala desa dan lurah untuk tingkatan ini adalah adanya kewenangan pengawasan sehingga dapat melakukan pendekatan secara persuasive terhadapa para pelaku usaha yang notebene adalah warga mereka sendiri.

Untuk pengembangan organisasi, sejalan dengan Pietropaolo (2015) dalam Valibeigi (2019: 8), dua tantangan utama dapat diidentifikasi: tantangan pertama terkait dengan desentralisasi proses. Yang diperlukan orientasi masih diperlukan untuk mempromosikan aturan publik dan kebijakan yang menentukan peran dan tanggung jawab sektor publik dan swasta. Kapasitas lokal untuk berorganisasi tidak diperkuat, dan aturan untuk penugasan urusan tidak ditetapkan atau tidak diterapkan sepenuhnya. Kedua, beberapa mekanisme fungsional dan partisipasi social prosedur dalam manajemen risiko telah diprediksi, seperti LSM lingkungan atau manuver gempa dan keselamatan, tetapi mereka hanya menunjukkan tingkat fitur partisipasi yang terlihat, mewakili partisipasi simbolik, yang tidak memiliki berdampak pada partisipasi masyarakat yang nyata selama bencana. Memperkuat pengembangan organisasi, sebagai platform untuk kegiatan kolaboratif lokal, membutuhkan kemauan politik untuk mendelegasikan beberapa tanggung jawab kepada lembaga dan kebijakan sipil memfasilitasi kegiatan kelompok relawan dalam berbagai social daerah. Penerapan kebijakan partisipatif dan yang terkait kemauan politik dan penguatan keterampilan, berkaitan dengan pengetahuan dan kesadaran yang sesuai, dapat membantu memastikan public partisipasi selama bencana. Kurangnya keputusan berbasis ilmu pengetahuan, penggunaan larangan perjalanan ad-hoc, dan tanggapan lain yang tidak diinformasikan dan tidak terkoordinasi, memperburuk wabah ini baik sebagai krisis kesehatan maupun krisis ekonomi, Djalante, Shaw, dan DeWit $(2020: 5)$

\subsubsection{Aspek Perencanaan}

Perencanaan yang baik akan mendorong daya antisipasi pemerintah terhadap peristiwa bencana alam akan lebih cepat. Sebab dengan melakukan perencanaan secara matang maka pemerintah dan masyarakat telah melakukan sebagian pekerjaan terkait dengan persiapan untuk menghadapi berbagai kemungkinan terjadinya bencana alam. Salah satu contoh minimnya perencanaan adalah pada saat pendemi telah terjadi pemerintah pada semua daerah di Indonesia baru mulai melakukan penyiapan tempat untuk menjadi pusat isolasi bagi para warga yang tertular secara lamngsung. Akibatnya adalah untuk kasus di Ternate adalah munculnya penolakan yang hamper merata dari semua masyarakat yang direncanakan lungkungannya akan menjadi pusat isolasi. Akibatnya adalah pemerintah dan tim gugus tugas melakukan isolasi pada beberapa hotel yang tentunya akan memiliki dampak pada biaya penanganan yang mahal. Pada jaman pemerintahan orde baru dahulu pada setiap desa didesain sebuah gedung yang disebut balai desa. Bangunan ini selanjutnya menjadi bangunan serba guna untuk kegiatan-kegiatan kemasyarakat di desa tersebut. Mulai dari tempat sosialisasi berbagai program-program pemerintah maupun pusat pemerintahan, dan lain-lain hajatan yang dilakukan untuk masyarakat desa.

Pola ini menunjukkan bahwa system perencanaan dahulu sudah ada dan perna sukses dilakukan di negeri ini. Dengan mengadopsi pola yang sama terus dibarengi dengan alokasi dana desa seperti saat ini tentu saja pemanfaatan balai desa tersebut akan semakin baik. Masih terkait dengan pola perencanaan tersebut adalah alokasi anggaran dana untuk penanganan bencana pun tidak selalu berjalan seperti yang daharapkan. Sehingga pada setiap terjadi bencana yang terjadi adalah mengharapkan partisipasi masyarakat yang bias saling membantu. Dengan menerapkan pola perencanaan yang baik tentu banyak hal yang dapat dilakukan oleh pemerintah. Termasuk didalamnya cara penanganan saat bencana dan pasca bencana. 
Ketidakmatangan perencanaan ini menyebabkan birokrasi kita hanya bersifat rekatif, bukan pro aktif.

\subsubsection{Aspek Kelembagaan}

Terdapat beberapa definisi terkait partisipasi (masyarakat), diantaranya menurut Davis (1962) sebagaimana dikutip oleh Rathnakar (2012: 136) mengatakan participation is define as mental and emotional envolvement of a person in a group situation which encourages him to contribute to group goals and share responsibilities in them. Berdasarkan pernyataan Davis tentang definisi diatas, maka partisipasi dapat diartikan sebagaiketerlibatan mental dan emosional seorang individu dalam situasi kelompok tertentu yang mendorongnya untuk berkontribusi untuk mencapai tujuan kelompok dan berbagi tanggung jawab di dalam pencapaian tujuan tersebut. Lebih lanjut Davis mengatakan bahwa kontribusi masyarakat dalam pencapaian tujuan (manajemen) pembangunan tersebut dilakukan dalam tiap-tiap tahapan mulai dari perencanaan perumusan agenda kerja pembangunan, pelaksanaan pembangunan, hingga evaluasi kegiatan pembangunan, Novie Indrawati Sagita (2016:311).

Memang tidak dapat dipungkiri bahwa dengan model partisipasi penuh masyarakat tersebut mulai dari aspek perencanaannya, pelaksanaan, dan evaluasinya dalam banyak riset, telah terbukti akan dapat mendorong peran aktif masyarakat untuk mencapai tujuan yang telah diotetapkan bersama tersebut. Inilah yang banyak diaplikasi dalam organisasi maupun kelompok kerja modern saat ini. Sebab dalam komunitas yang berada pada sector perkotaan yang memiliki tingkat kesibukan yang tinggi aktifitas social mulai berkurang. Oleh karena masing-masing sibuk dengan kegiatan rutinitasnya masing-masing. Kegiatan seperti pelibatan masyarakat seperti akan menjadi sebuah alas an tersendiri untuk dapat berinteraksi dengan komunitasnya tanpa ada yang harus merasa kehilangan posisi tawarnya.

Cameron dan Steven (2020:2) mengungkapkan bahwa dalam penanggulangan bencana, normalisasi adalah penyeragaman aturan, standar praktik, dan tujuan pengurangan resiko bencana yang dapat secara luas diterapkan keseluruh masyarakat. agar efektif, normalisasi dilegitimasi melalui penggunaan para ahli, yang dalam konteks penanggulangan bencana di Australia, para ahli ini dibuktikan dengan berkonsultasi dengan organisasi riset ilmiah dan industry kekayaan bersama serta kepala layanan darurat Negara, universitas, dan lembaga akademik lainnya. Melalui legitimasi inilah normalisasi menjadi alat pendukung rezim biopolitik.

Seperti halnya yang dilakukan oleh pemerintag daerah di Korea, seperti berikut Pemerintah Seoul dan Gyeonggi-do, dengan populasi tertinggi di Korea, mengambil tindakan proaktif dari wabah awal. Pemerintah Kota Seoul segera membuat dan mendistribusikan pedoman tentang prosedur masuk khusus yang merinci diagnosis dan tip pencegahan untuk virus korona, dan untuk sementara membatasi penggunaan kotak publik besar (Shaw; Kim; Hua : 2020:8)

Hal ini juga terkait dengan kepercayaan sebagian masyarakat yang mengkaitkan antara terjadinya berbagai peristiwa bencana alam tersebut dengan adanya ketentuan takdir yang memang harus dihadapi oleh masing-masing manusia.. tingkat kepasrahana sepertini niselanjutnya juga terserap ke dalam pelaksanaan birokrasi, mulai dari tahapan penerencanaan sampai pada tahapan evaluasi lebih banyak tertuju kepada pembangunan fisik dan melupakan kepada penguatan sikap dan pembentukan sikap masyarakat di dalam penanganan bencana dan penanganan pasca bencana.

Pada beberapa penelitian ini terkait juga dengan budaya nasional kita seperti yang telah dilakukan oleh Geer Hofstede, tentang budaya nasional yang membagi dimensinya dalam lima dimensi. Pada salah satu dimensinya yaitu uncertainty avoidance menempatkan Indonesia pada posisi low cenderung ke moderat. Yang 
artinya bahwa penghindaran terhadap ketidakpastian kita itu tergolong rendah. artinya kita lebih cenderung menerima terhadap kondisi ketidakpastian atau lebih menerima kondisi demikian. Oleh sebab itu kita tidak berusaha untuk membuat sesuatu yang tidak pasti itu menjadi sesuatu yang pasti. Seperti yang kita sudah tahu bahwa kendati kita saat ini berada di ring of fire yang memiliki potensi yang sangat tinggi terhadap kemungkinan terjadinya bencana tetapi kita tidak berupaya melakukan sesuatu yang secara sistematik secara ilmiah bias dipertanggungjawabkan untuk bisa menghindarkan kita dari berbagai kemungkinan terjadinya bencana alam tersebut. Secara sederhana seperti tidak adanya perencanaan, legislasi, dan lain-lainnya.

\subsubsection{Aspek Pendanaan}

Demikian juga pada aspek pendanaan, hamper tidak ditemukan sebuah kelurahan di lingkungan Kota Ternate yang menjadi objek kajian ini yang telah memiliki sebuah mekanisme pendaaan yang berasal dari swadaya masyarakat secara rutin. Untuk itu, jika terjadi suatu bencana hal yang dilakukan adalah dilakukannya iuran atau bahkan baru dibentuk tim pengumpul dana. Untuk itu, satu hal yang perlu dilakukan terkait dengan pelembagaan tersebut di atas adalah termasuk didalamnya adalah pembentukan mekanisme pendanaan yang berasal dari masyarakat secara rutin. Untuk itu, perlu dilakukan sebuah pemetaan masyarakat dari status ekonominya untuk dapat lebih mudah dilakukan pengumpulan. Hal ini perlu dilakukan agar dapat diperkirakan kemampuan masing-masing masyarakat dalam berkontribusi langsung terkait penyediaan anggaran tersebut. Selain itu, tentunya dari pihak pemerintah di tingkat kelurahan juga diharapkan adanya penganggaran secara rutin atas masalah ini.

Shah (2020:abstrak), menunjukkan bahwa otoritas manajemen bencana mengalami tumpang tindih yurisdiksi, duplikasi tanggung jawab, kurangnya sumber daya anggaran dan non anggaran, dan koordinasi di semua tingkatan. Instrument hokum dan kebijakan terkait bencana masih terbatas dalam penegakannya. Sindrom ketergantungan ada di ketiga tingkatan mekanisme kelembagaan dan pengarusutamaan PRB ke dalam pembangunan kurang dihargai di banyak proyek pembangunan.

\subsubsection{Aspek Pengembangan Kapasitas}

Untuk aspek pengembangan kapasitas seperti terlihat pada tabel tersebut di atas pada umumnya belum juga berjalan. Hal ini tentu merupakan sebuah konsekwensi logis dari belum berjalannya beberapa aspek lainnya. Sebab untuk dapat dilakukannya pengembangan kapasitas tentu saja para personil telah terorganisir di dalam sebuah wadah dan program paket pengembangan kapasitas telah tersusun dengan baik. Pada data tersebut di atas hanya pada kelurahan tertentu saja yang telah berjalan, akan tetapi perlu dilakukan penelusuran lebih jauh terkait dengan berjallannya program tersebut.

Pada banyak wilayah aspek pengembangan kapasitas ini banyak diisi dengan kegiatan penguatan ketrampilan serta penguatan emotional question. Hal ini tentu dikaitkan dengan tujuan dari program ini yaitu dipersiapkan untuk dapat melakukan penanganan jika sewaktu-waktu dibutuhkan jika terjadi musibah, baik itu terjadi di lingkungan masyarakat sendiri maupun di lingkungan lainnya yang dapat dilakukan mobilisasi ke wilayah tersebut. Untuk penguatan ketrampilan tentu dikaitkan dengan pemantapan fisik dan berbagai kegiatan kemanusiaan untuk penanganan korban, penanganan llogistik maupun penanganan daerah bencana. Sementara itu, untuk program penguatan emotional question diberikan untuk penguatan mental, kerja sama tim, dan kepercayaan diri para peserta, serta penguatan rasa empathy terhadap sesame manusia. 
Orang Tionghoa menunjukkan kekuatan tingkat solidaritas komunitas untuk orang-orang yang terkena dampak di Wuhan. Tidak hanya mereka yang menyediakan sumber daya, termasuk keuangan, sumber daya manusia, mereka juga membantu meningkatkan moral para petugas kesehatan garis depan, dan berbagi cerita dan pengalaman positif yang berbeda melalui social media, (Shaw; Kim; Hua : 2020:10).

Meskipun melalui hasil riset yang dilakukan oleh Boas (2020:7) menguraikan hasil penelitiannya bahwa dalam situasi bencana, warga kota China menggunakan dan menghargai sumber informasi tradisional dari pada media social. Bahkan dalam penggunaan media social, informasi yang dibagikan masih terutama diambil dari sumber informasi resmi (misalnya prakiraan cuaca) atau laporan media. Analisis blog media social memberikan gamaran serupa. Mayoritas postingan menganalisis informasi yang diuraikan atau diteruskan dari sumber resmi pemerintah atau media arus utama.

Lebih lanjut menurut Boas (2020:2), adalah bahwa terlepas dari optimism tentang peran penting media social ini sebelum, selama, dan setelah bencana, ada banyak kendala dan kerugian dari meningkatnya ketergantungan pada teknologi informasi dan media social. Salah satu resiko yang signifikan adalah tingginya potensi penyebaran fakta yang tidak akurat atau menyesatkan, terutama dalam situasi kekacauan.

Seperti yang dikatakan oleh Carter et all (2020: 9-10), terkait factor terakhir yang perlu dipertimbangkan adalah sejauh mana orang akan benar-benar dapat menggunakan pengetahuan tambahan yang mereka peroleh dari kampanye informasi pra-insiden dalam kejadian nyata sejauh mana rasa takut dan kecemasan yang dialami selama insiden tersebut melebihi manfaat yang terkait dengan peningkatan pra insiden. Seperti yang berhasil dibutikan bahwa kampanye informasi pra-insiden yang efektif akan mengurangi factor-faktor yang terkait dengan peningkatan kecemasan (misalnya kurangnya pengetahuan tentang resiko, persepsi bahwa resiko tidak terkendali) dan dengan demikian akan membantu mengatasi kecemasan dan memberdayakan orang untuk mengambil tindakan tepat.

\subsubsection{Aspek Penanggulangan Bencana}

Selanjutnya pada aspek penanggulangan bencana yang terkait dengan pandemic covid 19 ini, hamper semuanya diserahkan kepada tim gugus yang dibentuk oleh pemerintah. Hal ini yang menyebabkan banyak informasi yang tidak dapat disampaikan secara sempurna dari tim kepada masyarakat. Pada sisi yang lain juga ada sumber-sumber berita yang juga dikunsumsi secara luas oleh masyarakat. Akibatnya adalah masyarakat sulit untuk dapat membedakan informasi yang benar. Pada akhirnya adalah masyarakat memiliki pemahaman yang bias. Kondisi ini membuat perspektif masyarakat banyak bertentangan dengan tim penanganan di lapangan. Ujungnya sering terjadi konflik dan benturan.

Kalau saja aspek keenam ini, yakni tentang penanganan bencana telah berjalan secara baik dan normal di semua kelurahan, walaupun dengan karakteristik covid 19 mengharuskan terjadinya pembatasan interaksi di masyarakat, maka akan dapat dilakukan secara baik. Melalui pemanfaatan teknologi dengan berbagai media social yang saat ini berkembang di masyarakat tentu saja bias informasi dapat dikurangi. Bahkan juga mungkin dapat ditiadakan. Seperti yang telah dilakukan di Korea dalam masa pandemic saat ini, yakni meningkatkan tanggung jawab diri dan meningkatkan efisiensi administrasi menggunakan TIK: Korea Centers for Disease Control and Prevention (KCDC) mengembangkan aplikasi seluler diagnosis mandiri untuk memperkuat pemantauan dengan memungkinkan domestik dan asing pelancong yang memasuki Korea untuk mendiagnosis sendiri demam dan kondisi kesehatan terkait COVID-19, dan melaporkannya ke pusat kesehatan setempat atau 
KCDC. Saat pengguna mengetik informasi terkait karantina seperti informasi paspor, kewarganegaraan, dan nama di aplikasi, KCDC dapat memantau status mereka selama mereka tinggal di Korea, (Shaw; Kim; Hua : 2020:9).

Penilaian resiko bencana adalah pendekatan standar dalam PRB. Metodologi inti untuk penilaian resiko bencana mencakup penilaian bahaya dan kerentanan. Metode-metode ini dapat digunakan untuk penilaian resiko Covid - 19, Djalante (2020:5). Selain itu perlunya pelibatan dorongan untuk keterlubatan kesehatan yang lebih besar di dalam aspek PRB, Banwell (2018:7).

Selain itu, Peng et all (2020:abstrak) mengungkapkan bahwa kepercayaan antar pribadi memainkan peran penting di dalam memotivasi participation community based disaster management. Kepercayaan institusional dapat meningkatkan partisipasi dengan meningkatkan keterikan tempat. Kemanjuran dirio dan identitas perempuan memperkuat hubungan antar kepercayaan interpersonal dan PCBDM.

Meskipun terdapat bukti yang jelas tentang pemberdayaan perempuan dan peningkatan kapasitas, keberlanjutan inisiatif sangat bergantung kepada komitmen pemerintah daerah untuk memasukkan inisiatif ke dalam kebijakan dan tindakan local. Masih ada kesenjangan antara aspirasi untuk mempraktikkan pemberdayaan perempuan dan implementasinya, Ruszczyk (2020: abstrak).

Bahwa pelajaran penting dari kasus pandemic covid 19 ini adalah pelibatan komunitas masyarakat secara luas di dalam nebyelesaikan berbagai persoalan yang terjadi di sekitar masing-masing. Bahwa tingkat modernitas dan segala kompleksitasnya seharusnya tidak dapat menggeser kebersamaan. Sebab melalui kebermasaan akan dapat tangani masalah masyarakat secara bersama dengan cara yang paling sesuai dan baik untuk semua.

\section{KESIMPULAN DAN SARAN}

\subsection{Simpulan} berikut:

Berdasarkan pada hasil pembahasan di atas, maka dapat disimpulkan sebagai

1. Tingkat ketangguhan 10 kelurahan di Kota Ternate yang dijadikan sebagai objek kajian masih tergolong pada kategori rendah. Hal ini karena baru terdapat 3 Kelurahan yang terkategori madya, 5 Pratama, dan bahkan ada sebanyak 2 kelurahan yang belum masuk kategori.

2. Tingkat ketangguhan kelurahan terhadap bencana yang berada pada kategori rendah tersebut turut berpangruh terhadap penanganan pandemic covid 19 di Kota Ternate di lingkungan masing-masing. Sebab minimnya perencanaan dan menyebabkan persiapan pemerintah dalam menghadapi wabah yang sangat cepat meluas tersebut sangat mnim, bahkan terkesan terjadi kegugupan.

3. Belum kuatnya pelembagaan tentang penanganan bencana kepada masyarakat secara luas menyebabkan tingkat pemahaman masyarakat terhadap penanganan bencana menjadi rendah akibatnya adalah tingkat kesadaran dan rasa simpati masyarakat terhadap masyarakat lainnya menjadi rendah. Kondisi ini mendorong munculnya sikap masyarakat yang bertentangan dengan protap penanganan pendemi covid.

4. Belum dijadikannya penanganan bencana sebagai salah satu prioritas pemerintah menjadikan penanganan bencana termasuk covid 19 selalu terkesan lamban.

\subsection{Saran}

Berdasarkan pada klesimpulan tersebut, dapat dirumuskan beberapa saran sebagai sebuah rekomendasi yang dapat diajukan kepada para pihak yang terkait dengan penanganan bencana, adalah sebagai berikut: 
1. Keberadaan Kota Ternate di kawasan Ring of Fire harusnya meningkatkan kewaspadaan pemerintah daerah dengan berupaya meningkatkan tingkat ketangguhan semua kelurahan di wilayahnya dengan menjadikannya sebagai salah satu prioritas.

2. Berbagai aspek yang terkait dengan domain pemerintah di dalam penanganan bencana seperti aspek legislasi, penganggaran, penguatan kapasitas, dan penanganan bencana harus dilakukan penguatan secara signifikan dan berlangsung secara berkesinambungan.

3. Masyarakat sebagai subjek dari pembangunan harus dilibatkan secara penuh, termasuk juga di dalam hal penanganan bencana. Dengan demikian tingkat tanggung jawab masyarakat akan semakin tinggi dan akan dapat mendorong partisipasi masyarakat secara langsung untuk dapat terlibat di dalamnya menyukseskannya.

4. Keterbatasan riset ini karena hanya dapat dilakkan pada 10 kelurahan atau sekitar $13 \%$ dari total kelurahan menyebabkan kesimpulan ini belum menggambarkan data profil tingkat ketangguhan seluruh kelurahan di Kota Ternate. Demikian juga pada saat penelitian adalah masa di mana terjadinya pandemic secara tinggi sehingga menyebabkan penggalian data secara langsung mengalami kendala. Untuk itu, pada tahun yang akan dating penelitian pada tahun yang akan datangm penelitian ini akan diperluas mencakup seluruh kelurahan yang belum masuk pada penelitian ini.

5. Temuan penelitian dapat ditindaklanjuti dengan melakukan kegiatan pengabdian kepada masyarakat untuk membantu pemerintah di tingkat kelurahan dalam menyempurnakan pencapaian pada semua aspek yang ada.

\section{DAFTARPUSTAKA}

Alifa, Syadza; Wibowo, Arif. 2015. Peran Kelompok Rentan dalam Penanggulangan Bencana Dan Pengurangan Resiko Bencana di Desa Tangguh Bencana (Studi Deskriptif Satuan Tugas Desa Tangguh Bencana di Desa Gunung Geulis, Kecamatan Sukaraja, Kabupaten Bogor). Jurnal Ilmu Kesejahteraan Sosial. Jilid 16, Nomor 1, April 2015, 16-32.

Arie Priambodo. 2013. Panduan Praktis Menghadapi Bencana. Yogyakarta: Kanisius

Arikunto, S. 2002. Metodologi Penelitian Suatu Pendekatan Proposal. Jakarta: PT. Rineka Cipta.

Atkinson, Cameron; Curnin, Steven. 2020. Sharing responsibility in disaster management policy. Progress in Disaster Science.

Banwell, Nicola; Rutherford, Shannon; Mackey, Brendan; Chu, Cordia. 2018. Towards Improved Linkage of Disaster Risk Reduction and Climate Change Adaptation in Health: A Review. International Journal of Environmental Research and Public Health.

Boas, Ingrid; Chen, Chunci; Wiegel Hanne; He, Guizhen. 2020. The role of social media-led and governmental information in China's urban disaster risk response: The case of Xiamen. International Journal of Disaster Risk Reduction.

Carter, Holly; Drury, John; Amlot, Richard. 2020. Recommendations for improving public engagement with pre-incident information materials for initial response to a chemical, biological, radiological or nuclear (CBRN) incident: A systematic review. International Journal of Disaster Risk Reduction.

Djalante, Riyanti; Shaw, Rajib; DeWit. Andrew. 2020. Building resilience against biological hazards and pandemics: COVID-19 andits implications for the Sendai Framework. Progress in Disaster Science.

Hidayati, Deny. 2008. Kesiapansiagaan Masyarakat: Paradigma BAru Pengelolaan Bencana Alam di Indonesia. Jurnal Kependudukan Indonesia. Vol. III. No. 1. 69 - 84.

Idrus, 2007. Penelitian Kualitatif. 80-184

Kohler A, Jülich S, and Bloemertz L, 2004. Risk Analysis - a Basis for Disaster Risk Management. Risk Manag., pp. 18-67. 
Kusumasari, Bevaola. 2014. Manajemen Bencana dan Kapabilitas Pemerintah Lokal. Yogyakarta : Gava Media

Masyhuri dan M. Zainuddin. (2008). Metodologi Penelitian Sosial dan Ekonomi, Teori dan Aplikasi. Penerbit Alfabeta. Bandung.

Mojtaba Valibeigi1 Majid Feshari2 Fatemeh Zivari1 Artemis Motamedi. 2019. How to improve public participation in disaster risk management: A case study of Buein Zahra, a small city in Iran. Jàmbá - Journal of Disaster Risk Studies ISSN: (Online) 2072845X, (Print) 1996-1421.

Montes, Omar Yassef Antunes; Buonsensu, Danilo; Ortega, Sergio Omar Paz. 2020. Rationale For The Routine Application of Lung Ultrasound In The Manajegement of Corona Virus Disease 2019 (COVID-19) Patients In The Middle To Low Income Countries. Ultrasound in Med. \& Biol., Vol. 46, N0.9 pp 2572 - 2574.

Nasution, M. Syafii. 2005. Penanggulangan Bencana Berbasis Komunitas : Studi Kasus Kesiapsiagaan Bencana Berbasis Komunitas Daerah Rawan Bencana Alam Tanah Longsor Di Desa Kidangpananjung Kecamatan Cililin Kabupaten Bandung Jawa Barat. Bogor.

Partisipasi Warga Masyarakat Dalam Penilaian KInerja Kecamatan di Kota Bandung. 2019. Novie Indrawati Sagita Departemen Ilmu Pemerintahan FISIP Universitas Padjadjaran

Peng, Li; Tan Jing; Deng, Wei; Liu, Ying, 2020. Farmers' participation in community-based disaster management: The role of trust, place attachment and self-efficacy. International Journal of Disaster Risk Reduction.

Pradana, Y. A. 2012. Studi Ketahanan Masyarakat Pesisir Pacitan Terhadap Bencana Tsunami. Surabaya: POMITS.

Rahman, A. Z. (2017). Kapasitas Daerah Banjarnegara dalam Penanggulangan Bencana Alam Tanah Longsor. Jurnal Ilmu Sosial, 16(1), 1-8.

Restu Faizah, Willis Diana, Edi Hartono. 2018. Peningkatan Ketangguhan Masyarakat Dusun Godegan Jamuskauman Nglawur Magelang Jawa Tengah. Program Studi Teknik Sipil, Universitas Muhammadiyah Yogyakarta Jalan Brawijaya, Geblagan, Tamantirto, Kasihan, Bantul, Daerah Istimewa Yogyakarta 55183

Ruszczyk, Hanna A. 2020. Empowering women through participatory action research in community-based disaster risk reduction efforts. International Journal of Disaster Risk Reduction.

Shah, Ikram et all. 2020. Institutional arrangement for disaster risk management: Evidence from Pakistan. International Journal of Disaster Risk Reduction.

Shaw, Rajib; Kim ; Yong-kyun; Hua, Jinling. 2020. Governance, technology and citizen behavior in pandemic: Lessons from COVID-19 in East Asia. Progress in Disaster Science.

Sugiyono, 2000, Metode Penelitian Bisnis, Bandung : CV Alfabeta.

Surono. 2003. Potensi Bencana Geologi di Kabupaten Garut. Prosiding Semiloka Mitigasi Bencana Longsor di Kabupaten Garut. Garut: Pemerintah Kabupaten Garut.

Thomalla, Frank et all. 2006. Reducing hazard vulnerability: towards a common approach between disaster risk reduction and climate adaptation. Published by Blackwell Publishing, 9600 Garsington Road, Oxford. USA. 39 - 48.

Z, W. Guan, et all. 2020. Clinical Characteristics of Coronavirus Disease 2019 in China. The New England Journal of Medicine. 